\title{
Fibroblast Growth Factor-Inducible-14 Is Induced in Axotomized Neurons and Promotes Neurite Outgrowth
}

\author{
Katsuhisa Tanabe, ${ }^{1}$ Iris Bonilla, ${ }^{1}$ Jeffrey A. Winkles, ${ }^{2}$ and Stephen M. Strittmatter ${ }^{1}$ \\ ${ }^{1}$ Departments of Neurology and of Neurobiology, Yale University School of Medicine, New Haven, Connecticut 06510, and ${ }^{2}$ Vascular Biology Department, \\ Jerome H. Holland Laboratory for the Biomedical Sciences, American Red Cross, Rockville, Maryland 20855
}

For successful nerve regeneration, a coordinated shift in gene expression pattern must occur in axotomized neurons. To identify genes participating in axonal regeneration, we characterized mRNA expression profiles in dorsal root ganglia (DRG) before and after sciatic nerve transection. Dozens of genes are differentially expressed after sciatic nerve injury by microarray analysis. Induction of SOX11, FLRT3, myosin-X, and fibroblast growth factor-inducible-14 (Fn14) mRNA in axotomized DRG neurons was verified by Northern analysis and in situ hybridization. The Fn14 gene encodes a tumor necrosis-like weak inducer of apoptosis (TWEAK) receptor and is dramatically induced in DRG neurons after nerve damage, despite low expression in developing DRG neurons. Fn14 expression in PC12 cells is also upregulated by nerve growth factor treatment. Overexpression of Fn14 promotes growth cone lamelipodial formation and increases neurite outgrowth in PC12 cells. These Fn 14 effects are independent of the ligand, TWEAK. Fn 14 colocalizes with the Rho family GTPases, Cdc42 and Rac1. Furthermore, Fn14 physically associates with Rac1 GTPase in immunoprecipitation studies. The neurite outgrowth-promoting effect of Fn14 is enhanced by Racl activation and suppressed by Racl inactivation. These findings suggest that Fn14 contributes to nerve regeneration via a Rac1 GTPase-dependent mechanism.

Key words: nerve regeneration; growth cone; Fn14; TWEAK; Rho family GTPase; neurite extension; microarray

\section{Introduction}

In adult mammals, neurons of the peripheral nervous system (PNS) can regenerate an axon even after complete nerve transection. In contrast, axonal regeneration is minimal in the CNS. Several factors are likely to contribute to this marked and clinically important disparity in regeneration capacity. The environment surrounding the injured nerve differs between the PNS and CNS, partially accounting for the differential response to axonal injury. In the CNS, oligodendrocytes and glial scar tissue block regeneration by expression of inhibitory molecules such as Nogo, myelin-associated glycoprotein, oligodendrocyte myelin glycoprotein, and chondroitin sulfate proteoglycans (McKerracher et al., 1994; Fawcett and Asher, 1999; Niederost et al., 1999; GrandPre et al., 2000, 2002; Fournier and Strittmatter, 2001; Wang et al., 2002). The distal degenerating stump of a peripheral nerve lacks these axon growth inhibitors and is a fertile environment for the growth of axons. Indeed, CNS axons can extend long distances through transplanted peripheral nerve stumps or through a transplanted embryonic nervous system (Richardson et al., 1980; Coumans et al., 2001; Bregman et al., 2002).

Cell-autonomous factors also appear to specify the capacity for axonal regeneration, regardless of extracellular factors. Adult

\footnotetext{
Received May 23, 2003; revised July 21, 2003; accepted July 24, 2003.

This work was supported by National Institutes of Health grants to S.M.S. and J.A.W. and by a grant from the McKnight Foundation for Neuroscience to S.M.S. S.M.S. is an Investigator of the Patrick and Catherine Weldon Donaghue Medical Research Foundation. We thank Patrick Donohue for technical assistance.

Correspondence should be addressed to Stephen M. Strittmatter, Department of Neurology, Yale University School of Medicine, P.0. Box 208018, 333 Cedar Street, New Haven, C 06510. E-mail: stephen.strittmatter@yale.edu. Copyright $\odot 2003$ Society for Neuroscience $\quad$ 0270-6474/03/239675-12\$15.00/0
}

CNS neurons never extend axons as rapidly as do their embryonic or PNS counterparts (Goldberg et al., 2002). Peripheral nerve injury before central injury appears to induce a growthcompetent state that allows a degree of CNS growth from the central process of the same neuron injured peripherally (Chong et al., 1999; Neumann and Woolf, 1999). This "conditioning" effect suggests that a program of gene expression uniquely induced by peripheral axotomy can support axon extension. Data from different paradigms indicate that signaling pathways mediated by cAMP (Qiu et al., 2002a,b) and Janus activated kinase (JAK)-signal transducer and activator of transcription (STAT) phosphorylation (Liu and Snider, 2001) may participate in changes in axonal regeneration competence.

One approach to advancing our understanding of the molecular determinants of axonal regeneration is to characterize gene expression profiles before and after peripheral nerve injury. Regeneration-associated genes (RAGs) have been identified using a range of methods, including differential-display PCR (Kiryu et al., 1995), expressed sequence tag analysis (Tanabe et al., 1999), differential screening of a subtractive cDNA library (Araki et al., 2001), subtractive hybridization (Costigan et al., 1998), and cDNA microarray analysis (Bonilla et al., 2002; Costigan et al., 2002). Known RAGs encode many classes of proteins, including but not limited to neurotrophin receptors (Funakoshi et al., 1993), cytoskeletal elements (Muma et al., 1990; Moskowitz and Oblinger, 1995), neuropeptides (Villar et al., 1989; Wakisaka et al., 1991), transcription factors (Tsujino et al., 2000), and molecular chaperones (Costigan et al., 1998; Lewis et al., 1999; Benn et al., 2002). The observation that many RAGs are developmentally prevalent genes has led to the notion that "regeneration recapit- 
ulates development." Growth-associated protein (GAP)-43 is perhaps the prototypical RAG and fits this paradigm (Skene and Willard, 1981; Skene, 1989). In a recent cDNA microarray study, we observed that the small proline rich protein $1 \mathrm{~A}$ (SPRR1A) is very strongly induced by peripheral axotomy and promotes axon growth (Bonilla et al., 2002); however, SPRR1A is not found in any developing neurons, so the development-regeneration link is not universal.

Here, we have extended the analysis of RAGs by using a more comprehensive and sensitive Affymetrix DNA microarray system. The data indicate that dozens of previously unrecognized RAGs exist, and our studies focused on one of these: fibroblast growth factor-inducible-14 (Fn14). Fn14 is a transmembrane protein (Meighan-Mantha et al., 1999) reported to be a receptor for tumor necrosis-like weak inducer of apoptosis (TWEAK), a member of the tumor necrosis factor (TNF) superfamily of structurally related cytokines (Wiley et al., 2001). It has been reported that TWEAK is an angiogenic factor and that TWEAK binding to Fn14 promotes the proliferation of both human endothelial cells, leading to angiogenesis (Lynch et al., 1999; Wiley et al., 2001; Harada et al., 2002; Donohue et al., 2003), and astrocytes (Desplat-Jego et al., 2002). There is no reported neuronal function for Fn14. We show that Fn14 is induced in dorsal root ganglia (DRG) neurons during sciatic nerve regeneration and promotes neurite outgrowth through a mechanism that appears to involve the Rho family GTPase, Rac1.

\section{Materials and Methods}

Animal surgery and RNA isolation. Adult male C57BL/6 mice were anesthetized by intraperitoneal injection of 2,2,2-tribromoethanol (SigmaAldrich, St. Louis, MO). The sciatic nerve at the midthigh level was exposed and transected. For retrograde labeling, fluoro-gold (FG) was applied to the cut proximal end of the nerve at the time of the transection. Animals were killed 1, 4, 7, 14, 28, or $56 \mathrm{~d}$ after injury, and the ipsilateral DRG neurons from L4, L5, and L6 were placed into liquid nitrogen. Contralateral DRG neurons served as control. Total RNA was extracted with an RNeasy mini kit (Qiagen, Valencia, CA).

Microarray analysis. The total RNA from control and axotomized DRG samples was reverse-transcribed with $\mathrm{T} 7-(\mathrm{dT})_{24}$ primer (Affymetrix, Santa Clara, CA), and double-stranded cDNA was synthesized with Superscript Choice system (Invitrogen, Carlsbad, CA). Biotinlabeled cRNA was generated with a BioArray High Yield RNA transcript labeling kit (Enzo Diagnostics, Inc, NY). These cRNA samples were hybridized with Mouse Genome U74 A, B, and C arrays from Affymetrix.

Northern blot analysis. As templates, myosin-X (bp 4-627, BF536234), SOX11 (bp 40-382, BE854207), FLRT3 (bp 18-472, BE286611), and TWEAK (bp 78-561, AW763237) were amplified using PCR reaction from I.M.A.G.E. clones (Incyte Genomics, St. Louis, MO). The Fn14 cDNA fragment (bp 13-411, NM013749) was amplified from a pcDNAI/ Neo plasmid encoding influenza hemagglutinin (HA)-tagged Fn14 (Meighan-Mantha et al., 1999). Probes were synthesized from these cDNAs by random priming in the presence of $\left[\alpha^{-32} \mathrm{P}\right] \mathrm{dCTP}$. Northern blot analysis was conducted as described with $5 \mu \mathrm{g}$ samples of total RNA from DRG tissue or PC12 cells (Bonilla et al., 2002).

In situ hybridization. In situ hybridization was performed as described previously (Tanabe et al., 1999, 2000). Fn14 cDNA (bp 22-411, NM013749) and FLRT3 cDNA (bp 18-472, BE286611) were amplified by PCR and subcloned into pCR2Topo (Invitrogen). The SOX11 cDNA clone (bp 1873-2896, AF009414) was a generous gift from P. Koopman (University of Queensland, Queensland, Australia). In vitro transcription from linearized plasmids was performed using T7 and SP6 RNA polymerase and $\left[\alpha-{ }^{35}\right.$ S]UTP (DuPont NEN, Wilmington, DE) to prepare both antisense and sense riboprobes. After hybridization to tissue sections, mRNA localization was assessed with emulsion autoradiography.

Herpes simplex virus preparation. The enhanced green fluorescent protein (GFP) cDNA was amplified from pEGFP-N3 (Clontech, Palo Alto,
CA) and ligated to the pHSVprPUC vector (Nakamura et al., 1998; Takahashi et al., 1998, 1999). The full coding region of Fn14, Fn14 without the ectocellular domain (aa 77-129), or Fn14 without the cytoplasmic domain (aa 1-103) was amplified by PCR and ligated to the $\mathrm{N}$ terminus EGFP coding region of pHSVprPUC-GFP to express Fn14-GFP fusion protein. The ectocellular-deleted Fn14 mutant contains the translational start and signal sequence from pSecTag2/Hygro vector (Invitrogen). These plasmids were transfected into $2-2$ cells with Lipofectamine (Invitrogen) and superinfected with $5 \mathrm{dll} .2$ herpes simplex helper virus $1 \mathrm{~d}$ later as described (Nakamura et al., 1998; Takahashi et al., 1998, 1999).

Cell culture, transfection, and herpes simplex virus infection assay. PC12 cells were grown in DMEM with 10\% horse serum and 5\% fetal bovine serum. For herpes simplex virus (HSV) infection, cells were plated on glass chamber slides coated with poly-L-lysine $(100 \mu \mathrm{g} / \mathrm{ml})$ plus laminin $(10 \mathrm{mg} / \mathrm{ml})$ and then incubated in serum-free DMEM with N2 supplement. Cells were fixed $24 \mathrm{hr}$ after infection and stained with rhodaminephalloidin for visualization of F-actin. GAP- 43 was visualized with antiGAP43 polyclonal antibody and cyanine 3 (Cy3)-conjugated anti-rabbit $\operatorname{IgG}$ antibody. For cotransfection of individual Rho family proteins and Fn14, Bos expression vectors including myc-tagged Cdc42 (G12V, wild, or T17N), Rac1 (G12V, wild, or T17N) and RhoA (G14V, wild, or T19N) were kindly provided by Y. Takai (Osaka University, Osaka, Japan). PC12 cells were transfected with the plasmids expressing Rho family proteins using Lipofectamine2000 (Invitrogen) and replated to poly-L-lysine (100 $\mu \mathrm{g} / \mathrm{ml}$ ) plus laminin ( $10 \mathrm{mg} / \mathrm{ml})$-coated chamber slides $24 \mathrm{hr}$ after transfection. They were infected with HSVFn14-GFP virus and fixed $24 \mathrm{hr}$ after infection. Recombinant human TWEAK was obtained from Peprotech (Rocky Hill, NJ), and the extracellular domain of Fn14 fused with the $\mathrm{Fc}$ portion of murine IgG $(\mathrm{Fn} 14-\mathrm{Fc})$ was prepared as described (Donohue et al., 2003).

DRG neurons were removed from the L4-6 level from 8- to 10-weekold mice with or without sciatic nerve crush injuries 1 week previously. Neurons were dissociated, cultured, and infected with HSV preparations as described previously (Bonilla et al., 2002). After $24 \mathrm{hr}$ in culture, cells were fixed, and neurite outgrowth per GFP-expressing viral-infected neurons was scored as described (Bonilla et al., 2002). In these cultures, $50-80 \%$ of neurons were infected. Some cultures were collected after 24 $\mathrm{hr}$, and protein was analyzed by immunoblot for GFP and Fn14 expression.

COS-7 cells were transfected with Bos myc-Cdc42 (G12V, wild, or T17N), Rac1 (G12V, wild, or T17N), or RhoA (G14V, wild, or T19N) and pEGFP-N3 containing coding region of Fn14 (Meighan-Mantha et al., 1999) using Fugene 6 (Roche, Indianapolis, IN). The cells were fixed 24 hr after transfection, and Rho family GTPases were visualized with 9E10 c-Myc-antibody (Sigma-Aldrich) and Cy3-conjugated anti-mouse IgG antibody (Sigma-Aldrich).

Immunoprecipitation. Human embryonic kidney (HEK) 293T cells were transfected with pcDNA1-Fn14-HA (Meighan-Mantha et al., 1999) and Bos vectors encoding myc-Racl or myc-Cdc42. Transfected 293T cells were harvested and lysed at $4^{\circ} \mathrm{C}$ for $1 \mathrm{hr}$ in $50 \mathrm{~mm}$ Tris- $\mathrm{HCl}, \mathrm{pH} 8$, $150 \mathrm{~mm} \mathrm{NaCl}, 5 \mathrm{~mm} \mathrm{MgCl}$, $1 \%$ Triton X-100, 0.5\% deoxycholic acid, $0.1 \%$ SDS, and complete proteinase inhibitor mixture (Roche). The lysates were centrifuged at $13,000 \times g$ at $4^{\circ} \mathrm{C}$ for $20 \mathrm{~min}$, and the supernatants were collected. Samples were then incubated with an anti-Mycconjugated agarose (Santa Cruz Biotechnology, Santa Cruz, CA) for 14 $\mathrm{hr}$ at $4^{\circ} \mathrm{C}$. The agarose beads were centrifuged and washed five times with wash buffer, $50 \mathrm{~mm}$ Tris- $\mathrm{HCl}, \mathrm{pH} 8,150 \mathrm{~mm} \mathrm{NaCl}, 5 \mathrm{~mm} \mathrm{MgCl}, 1 \%$ Triton X-100, and complete proteinase inhibitor mixture. The bound Fn14 was detected by immunoblotting with anti-HA monoclonal antibody (Roche).

DRG samples were immunoblotted using anti-GFP (Clontech) and anti-Fn14 antibodies (Meighan-Mantha et al., 1999).

Rac1 activity assay. HEK293T cells were transfected with pcDNAI/ Neo-Fn14-HA or pcDNAI/Neo and lysed with $50 \mathrm{~mm}$ Tris-HCl, pH 7.5, $500 \mathrm{~mm} \mathrm{NaCl}, 0.1 \%$ SDS, $0.5 \%$ deoxycholate, $1 \%$ Triton X-100, $10 \mathrm{~mm}$ $\mathrm{MgCl}_{2}$, and complete proteinase inhibitor. The lysate was centrifuged at $13,000 \times g$ at $4^{\circ} \mathrm{C}$ for $20 \mathrm{~min}$, and the supernatant was incubated with 10 $\mu \mathrm{g}$ of GST-p21-binding domain of PAK-1 coupled to glutathione agarose at $4^{\circ} \mathrm{C}$ for $45 \mathrm{~min}$. The agarose beads were collected by centrifugation and washed with $50 \mathrm{~mm}$ Tris- $\mathrm{HCl}, \mathrm{pH} 7.5,150 \mathrm{~mm} \mathrm{NaCl}, 1 \%$ Triton 
Table 1. DRG mRNAs altered after sciatic axotomy

\begin{tabular}{|c|c|c|}
\hline Gene & Fold change & Previous report of regulation by axotomy \\
\hline Neuropeptide Y & 70.5 & Wakisaka et al., 1991 \\
\hline Neurotensin & 25.2 & Zhang et al., 1996 \\
\hline Complement component $1, q$ subcomponent & $16.9,15.1,5$ & Mattsson et al., 1998 \\
\hline ATF-3 & $16.8,5.2$ & Tsujino et al., 2000 \\
\hline Histocompatibility 2, class II antigen A, $\alpha$ & 13.4 & None \\
\hline Lysozyme P & 13.3 & None \\
\hline LIM domain only protein 7 & 13.1 & None \\
\hline Fibroblast growth factor inducible-14 (Fn14) & 9.6 & None \\
\hline FLRT3 & 9.5 & None \\
\hline A disintegrin and metalloprotease domain (ADAM) 8 & 9.1 & None \\
\hline Retinoid-inducible serine carboxypeptidase precursor (Risc) & 8.7 & None \\
\hline Acupuncture induced gene 1 (Aig1-pending), & 8.2 & None \\
\hline S0X11 & $8,6.8,6.7,5.8$ & None \\
\hline Al851735 & 7.9 & None \\
\hline Fibroblast growth factor-regulated protein (Fgfrp) & 7.8 & None \\
\hline 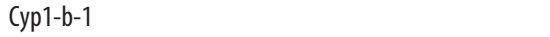 & 7.7 & None \\
\hline Glucosaminyltransferase, I-branching enzyme & 7.4 & None \\
\hline MHC class II H2-I-A- $\beta$ gene (k haplotype) & 7.4 & None \\
\hline Lysozyme M & 7.4 & None \\
\hline AW125664 & 7.1 & None \\
\hline MT3-MMP(membrane-type matrix metalloprotease) & 7 & None \\
\hline ATP-binding cassette 1 & 7 & None \\
\hline Myosin X & 7 & None \\
\hline AA217038 & 6.6 & None \\
\hline IGF-binding protein 3 & 6.3 & None \\
\hline Galanin & 6.3 & Landry et al., 2000 \\
\hline GADD45 protein & 6.2 & None \\
\hline Protein tyrosine phosphatase, non-receptor type 1 (Ptpn1) & 5.9 & None \\
\hline MPS1 & 5.7 & None \\
\hline Ion channel homolog RIC & 5.7 & None \\
\hline Lipocortin 1 = annexin-1 & 5.6 & None \\
\hline AW123573 & 5.4 & None \\
\hline AW125276 & 5.1 & None \\
\hline Mitogen-responsive 96 kDa phosphoprotein p96 & 5 & None \\
\hline Al834969 & -5.2 & None \\
\hline AW061035 & -5.6 & None \\
\hline
\end{tabular}

Those genes with expression level that is altered more than fivefold 1 week after sciatic nerve transection are listed. The genes studied here are in bold.

$\mathrm{X}-100,10 \mathrm{~mm} \mathrm{MgCl}_{2}$, and complete proteinase inhibitor. The bound GTP-Rac1 was detected by immunoblotting with anti-Rac1 monoclonal antibody (Upstate Biotechnology, Lake Placid, NY).

\section{Results}

Microaray expression profile of nerve injury-related genes

In previous experiments, Incyte microarrays consisting of PCR products derived from Unigene expressed sequence tags (ESTs) were used to compare DRG mRNAs before and $7 \mathrm{~d}$ after sciatic nerve transection (Bonilla et al., 2002). Hybridization signals were detected for only 1500 of $8000 \mathrm{cDNAs}$ on these arrays, so that a very incomplete survey of RAGs was obtained. Here, Affymetrix arrays covering 6000 mouse full-length cDNAs and $\sim 30,000$ EST clusters were used in the same experimental paradigm. Not only did this provide greater coverage of the genome, but the method is more sensitive, yielding detectable hybridization signals for $24 \%$ of genes. In an initial comparison at $7 \mathrm{~d}$ after injury, it was clear that there are many more differentially expressed genes detected by this method. Using a stringent cutoff for further analysis (more than or equal to fivefold change), 36 different mRNAs were upregulated and two were downregulated (Table 1). In contrast, only two genes would have met this criterion in our previous studies (Bonilla et al., 2002). Among the upregulated genes, five had previously been reported to be induced by peripheral nerve transection (Wakisaka et al., 1991; Zhang et al., 1996; Mattsson et al., 1998; Landry et al., 2000;
Tsujino et al., 2000), supporting the validity of this method. The other 31 genes were detected for the first time here as RAGs. We could separate the 36 genes into several categories: neuropeptides (neuropeptide Y, galanin), immune system-related (complement C1q, histocompatibility class 2 antigen), transcription factors (ATF-3, SOX11), cellular metabolism (lysozyme P, glucosaminyltransferase, lysozyme M), cytoskeletal (myosin-X), and others. Both of the downregulated genes were unknown EST clones. Several known RAGs were upregulated, but the numerical values did not meet this stringent cutoff. This group included SPRR1A (more than or equal to fourfold, with no signal above background in control samples), heat shock protein (HSP)-27 (more than or equal to twofold, with no signal above background in control DRG samples), and GAP-43 (2.3 fold). Other known RAGs, such as CAP23 and Reg-1, are not represented on the chip.

\section{Expression profile of myosin-X, SOX11, and FLRT3 before} and after nerve injury

To generate a genome-wide analysis of expression patterns in nerve regeneration, it will be necessary to obtain a complete expression profile at multiple time points with statistical analysis of gene clusters from numerous repetitions of this experiment. Instead, we focused here on validation and functional studies for several selected genes derived from the initial screen. Four genes were studied further: myosin-X, SOX11, FLRT3, and Fn14. Some 
function and expression data have already been provided for each of these, but no studies have investigated their role in the nervous system generally or in axonal regeneration specifically.

As a first step, we sought to validate the microarray expression changes by Northern blot analysis of control and $7 \mathrm{~d}$ postsciatic nerve injury DRG RNA samples (Fig. 1A). Myosin-X has two transcript forms in adult mouse tissue, a full-length form $(8.7 \mathrm{~kb})$ and a shorter form deleting $\mathrm{N}$-terminal head region $(7.0 \mathrm{~kb})$, with a third short isoform $(4.8 \mathrm{~kb})$ in embryonic tissue (Berg et al., 2000; Yonezawa et al., 2000). In myosin-X Northern blot hybridizations, four weak signals ( 8.7, 7.0, 4.8, and $1.8 \mathrm{~kb}$ ) are seen in control DRG tissue, and all of these transcripts are upregulated to some degree by nerve injury. In embryonic day 15 (E15) and neonatal day 3 (P3) samples, the 8.7 and $7.0 \mathrm{~kb}$ transcripts were more highly expressed than in uninjured adult DRG.

For SOX11, a previous study had demonstrated a single transcript of $3.5 \mathrm{~kb}$ in the whole mouse embryo (Hargrave et al., 1997), whereas in human and chicken two transcripts ( 9.5 and $3.0 \mathrm{~kb}$ ) were observed (Jay et al., 1995; Uwanogho et al., 1995). In our study, a low level of SOX11 mRNA expression was detected $(3.5 \mathrm{~kb})$ in control adult DRG. In contrast, axotomized DRG samples express much higher levels of the $3.5 \mathrm{~kb}$ SOX11 transcript, with detectable levels of three minor transcripts $(9.5,4.8$, and $2.0 \mathrm{~kb}$ ). Uninjured E15 DRG expression of all four SOX11 transcripts is strong, and expression is downregulated to adult levels by $\mathrm{P} 3$.

In human tissues, FLRT3 was detected as a single transcript of $4.4 \mathrm{~kb}$ (Lacy et al., 1999). In our mouse control adult DRG Northern blots, a single weak signal is also present at $4.0 \mathrm{~kb}$. FLRT3 mRNA expression is dramatically increased after nerve injury, and E15 DRG have higher expression than adult control DRG. In brief, the microarray data for myosin-X, SOX11, and FLRT3 are confirmed by Northern blotting. In each case, the upregulation after injury mirrored the high expression during development. These findings are consistent with the linked regeneration-development hypothesis.

Although the Northern analysis demonstrates DRG expression, it does not distinguish which cells express the mRNA of interest. If these proteins are to contribute to axonal regeneration, then neuronal expression would be consistent with a more direct role in the process. In situ hybridization studies were conducted for SOX11 and FLRT3 (Fig. $1 B$ ). Injured neurons were identified by retrograde labeling with FG applied at the time of injury to the proximal cut end of the sciatic nerve. Increased silver grain density reflecting hybridization to either FLRT3 or SOX11 mRNA is seen over cells in the injured DRG sections. Moreover, the increased grain density corresponds to the fluorescent label, demonstrating that these genes are induced in axotomized neurons. We have not made an extensive statistical analysis of SOX11 and FLRT3 colocalization with FG, but most of the FG-positive cells are SOX11 or FLRT3 positive after injury, suggesting that the induction is not DRG neuron-subtype specific.

\section{Expression profile of Fn14 and TWEAK during nerve regeneration}

Validation studies by Northern analysis and in situ hybridization were also performed for the Fn14 gene. The expression level of the $\sim 1.2 \mathrm{~kb}$ Fn14 mRNA is barely detectable in uninjured adult DRG or in developing DRG (E15 and P3); however, Fn14 mRNA is induced after axotomy (Fig. 2A). Thus, Fn14 is a RAG not subject to developmental regulation but specific to the regeneration process. Fn14 expression is increased $1 \mathrm{~d}$ after axotomy and is elevated further by postoperative days $4-7$. Thereafter, Fn14 mRNA expression gradually decreases to control levels by $56 \mathrm{~d}$ after axotomy (Fig. 2 B). By in situ hybridization Fn 14 expression is localized to injured DRG neurons retrogradely labeled with fluoro-gold from the axotomy site. Because $>80 \%$ of fluorogold-stained cells exhibit increased Fn14 mRNA, we conclude that there is little specificity of Fn 14 regulation among different DRG populations (Fig. 2C).

Recently, Fn14 was identified as a receptor for the TNFrelated cytokine TWEAK (Wiley et al., 2001). Therefore, we examined TWEAK mRNA expression in the DRG and in the proximal and distal nerve stumps before and after sciatic nerve injury (Fig. 2D). TWEAK mRNA level is the same in the control and axotomized DRG. TWEAK is moderately expressed in control sciatic nerve, and expression appears to be downregulated by nerve injury. Thus, there is no obvious correlation of changes in Fn14 and TWEAK gene expression during sciatic nerve regeneration. 
A

$\frac{\text { Fn14 }}{\text { E15 P3 Con Axo(7d) }}$

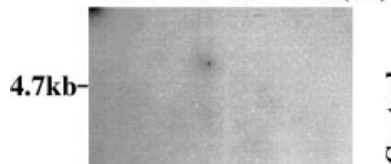

$1.8 \mathrm{~kb}$

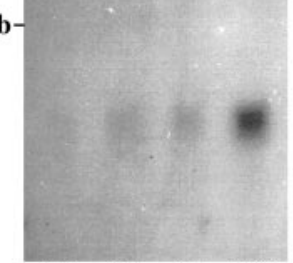

$\begin{array}{llll}1.0 & 3.5 & 3.5 & 13.2\end{array}$

C

FLUORO-GOLD
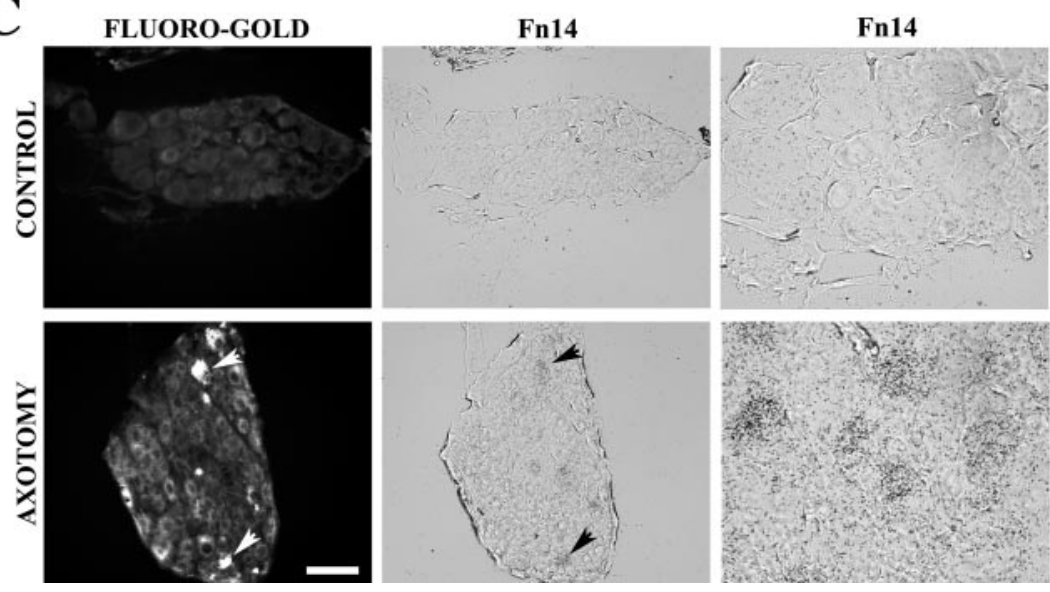

Figure 2. Fn14 mRNA expression is induced in DRG neurons by axotomy. A, B, Northern blot analysis of Fn14 mRNA expression in uninjured E15, uninjured P3, adult axotomized (Axo), and adult contralateral (Con) L4 - 6 mouse DRGs. Samples were collected at $7 \mathrm{~d}(A)$ or at various times $(B)$ after sciatic nerve injury. The ethidium bromide staining pattern of the 185 ribosomal RNA is shown to demonstrate the quantity of RNA loaded. The migration of $28 \mathrm{~S}$ and $18 \mathrm{~S}$ rRNA is shown at left, and the relative signal intensity is reported at the bottom of each lane. C, In situ hybridization shows colocalization of Fn14 mRNA in the fluoro-goldlabeled axotomized DRG (arrowheads) but not in control contralateral DRG sections. Scale bar: four left panels, $250 \mu \mathrm{m}$; two right panels, $50 \mu \mathrm{m}$. D, Northern blot analysis of TWEAK mRNA expression in uninjured E15, uninjured P3, adult axotomized, and adult contralateral L4-6 mouse DRGs and in proximal or distal injured nerve stumps. Samples were collected $7 \mathrm{~d}$ after sciatic nerve transection. The ethidium bromide staining pattern of the 185 ribosomal RNA is shown to demonstrate the quantity of RNA loaded.

Fn14 and TWEAK expression during PC12 cell differentiation PC12 pheochromocytoma cells can differentiate under appropriate culture conditions to a neuronal phenotype and have been widely used for studies of nerve growth factor (NGF) signal transduction, neuronal survival, and neurite outgrowth. To consider the potential role of Fn14 and TWEAK during PC12 neurite growth, we examined Fn14 and TWEAK mRNA expression levels in undifferentiated and NGF-treated PC12 cells by Northern blot analysis (Fig. 3). Fn14 expression is detectable in untreated cells and is moderately increased at $12 \mathrm{hr}$ after NGF addition. Peak Fn 14 mRNA expression occurs after $1 \mathrm{~d}$ in the presence of NGF, followed by a decline after $9 \mathrm{~d}$ in NGF. In contrast, TWEAK mRNA expression is detectable throughout differentiation and is not regulated by NGF treatment. These results indicate that the Fn14 receptor may be involved in NGF-induced PC12 neuronal differentiation.

\section{Fn14 induces neurite outgrowth in PC12 cells}

To explore a potential role for Fn14 in neurite outgrowth, wildtype and mutant forms of Fn14 were overexpressed by infection with a recombinant HSV vector (Fig. 4A). Within $20 \mathrm{hr}$ of expo- sure to the Fn14 virus, expression of the wild-type Fn14-GFP fusion protein is observed. In the absence of any added NGF, a significant percentage of Fn14-GFPexpressing PC12 cells extend long neurites on laminin-coated surfaces (Fig. $4 B, C$ ). Neuritogenesis is not observed in uninfected cultures or in GFP-expressing cells. This Fn 14 response is more rapid and robust than the response to NGF in the same time period. Fn14 activity requires both the ectodomain and the cytoplasmic domains, because expression of truncated mutant proteins has no neuritogenic effect in PC12 cells. No detectable change in cell viability is associated with Fn14 expression in this assay, as determined by cell counts (data not shown). It is clear that Fn14 overexpression can dramatically promote neuritogenesis from PC12 cells.

Because PC12 cells coexpress TWEAK and Fn14, we determined whether TWEAK could act in an autocrine manner to promote neuritogenesis. To enhance TWEAK function, purified TWEAK protein was added to the culture medium. To inhibit TWEAK function, an Fn14-Fc decoy receptor, consisting of the extracellular portion of Fn14 fused to the murine IgG1-Fc domain (Donohue et al., 2003), was added to the medium. Neither TWEAK nor Fn14-Fc promotes neurite extension from control PC12 cells (Fig. $4 D$ ). Furthermore, neither reagent alters Fn14-induced neuritogenesis. Thus, the Fn14 effect appears to be TWEAK independent in this system. The fact that the Fn14-Fc protein has no effect on Fn14induced neuritogenesis suggests that Fn14 is acting in a ligand-independent manner.

Adult DRG neurons extend neurites much more rapidly than PC12 cells, even after NGF differentiation. The effect of overexpressing wild-type Fn14 or the potentially dominant-negative Fn14 mutant form lacking the cytoplasmic domain (Fn14- $\Delta$ END) was examined in adult DRG neurons (Fig. 4E,F). L4-6 DRG neurons were cultured from naive animals (with low endogenous Fn14) and from animals with ipsilateral sciatic nerve lesion 1 week previously (with induced endogenous Fn14 expression). Fn14 wild-type overexpression did not significantly increase outgrowth compared with control GFP-expressing cultures. Fn14 wild-type overexpressing cells exhibit a very slight, but statistically significant, increase in outgrowth compared with Fn14- EENDexpressing cells. This minimal effect was significant only in naive cultures with low endogenous Fn14. As for PC12 cells, the addition of TWEAK ligand did not alter neurite outgrowth rates in adult DRG neurons (Fig. 4E).

\section{Fn14 induces filopodia and lamelipodia in PC12 cells}

The most readily apparent morphologic effect of Fn14 overexpression in PC12 cells is neuritogenesis. Closer examination, however, reveals additional morphologic changes. There is a striking increase in the presence of filopodial extensions from the 
A

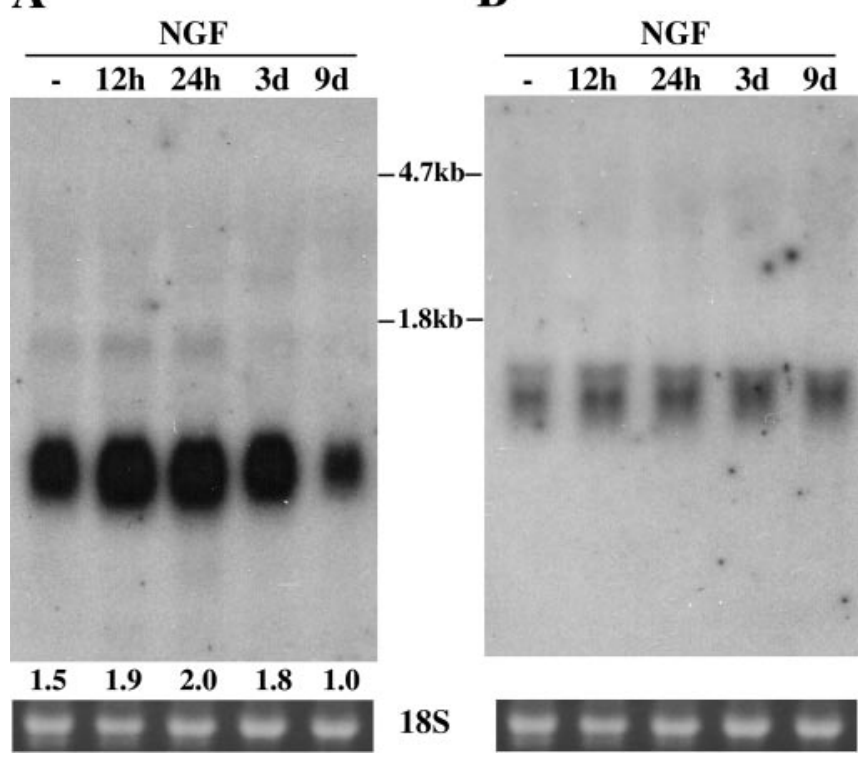

Figure 3. Fn14 and TWEAK mRNA expression in $\mathrm{PC} 12$ cells. $\mathrm{PC} 12$ cells were treated with NGF for various lengths of time and then harvested. Fn14 $(A)$ and TWEAK $(B)$ mRNA levels were examined by Northern blot. In $A$, the relative signal intensity for Fn14 mRNA is reported at the bottom of each lane. The ethidium bromide staining pattern of the 185 ribosomal RNA is shown to demonstrate the quantity of RNA loaded.

cell perimeter of Fn14-overexpressing cells. Although untreated or HSV-GFP-infected PC12 cells have short filopodia at the acute angles of the cell surface (Fig. 5A), Fn14-GFP-expressing cells exhibit numerous long filopodia extending from straight cell borders as well as from angular cell borders (Fig. 5B). Concomitant with increased filopodial formation, Fn14-GFP-expressing cells showed cell spreading and lamelipodia formation (Fig. 5C). Filopodia and lamelipodia formation is also seen in extending neurites (Fig. 5D,E).

Filopodial and lamelipodial structures are rich in F-actin and their formation is dependent on microfilament rearrangements. A comparison of Fn14-GFP and F-actin localization demonstrates extensive colocalization near the cell perimeter and in filopida and lamelipodia (Fig. 5B-E). GAP-43 has been localized to neuronal growth cones and has been considered a marker for regenerating neurites (Skene and Willard, 1981; Skene, 1989). Fn14-GFP-rich filopodia and lamelipodia contain abundant colocalized GAP-43 (Fig. 5F). It seems probable that Fn14 induction of F-actin/GAP-43-rich filopodia and lamelipodia is a precursor to neuritogenesis from PC12 cells. By these criteria, the neuritic morphology induced by NGF treatment and Fn14 overexpression share similarities at the cytoskeletal level.

\section{Fn14 promotes growth cone formation in differentiated PC12 cells}

The foregoing experiments demonstrate that Fn14 overexpression can promote the formation of PC12 neurites in the absence of NGF but do not reveal possible effects on neurites already established in NGF-treated cells. After $10 \mathrm{~d}$ of NGF treatment, PC12 cells exhibit extensive neurite outgrowth but most of the neurite tips display minimal lamelipodial growth cone-like specialization. To examine the effect of Fn14 overexpression on differentiated PC12 cells, cultures were infected with HSV-Fn14GFP or HSV-GFP virus. Fn14-GFP but not GFP-expressing cells show a significant increase in the percentage of well spread neu- ritic tips with growth cone widths $>10 \mu \mathrm{m}$ (Fig. 6A,B). As in the neuritogenesis assays, addition of TWEAK or Fn14-Fc did not enhance or inhibit growth cone formation (Fig. 6B). Thus, Fn14 promotes both growth cone formation and neuritogenesis by a mechanism that appears ligand independent.

\section{Fn14 interacts and colocalizes with Rac1 GTPase}

Rho family GTPases play a central role in modulating F-actin structures (Ridley and Hall, 1992; Kozma et al., 1995, 1997; Nobes and Hall, 1995; Hall, 1998) and thereby modulate neurite and growth cone motility (Mackay et al., 1995; Tanaka and Sabry, 1995; Jin and Strittmatter, 1997; Meyer and Feldman, 2002). For PC12 cells, it has been demonstrated that both activated Cdc42 and Rac lead to lamelipodia and cell spreading, whereas activated Cdc42 induces filopodia. Furthermore, effectors of Cdc42 and Rac cause PC12 neurite outgrowth (Daniels et al., 1998). Rac/ $\mathrm{Cdc} 42$ activation is required for neurite outgrowth in response to NGF (Chen et al., 1999; Yamaguchi et al., 2001; Yasui et al., 2001). In contrast, RhoA activation inhibits neurite outgrowth (Jalink et al., 1994; Tigyi et al., 1996; Jin and Strittmatter, 1997). The morphology of Fn14-overexpressing PC12 cells is remarkably similar to that of cells expressing activated Cdc42 or Rac1. On the basis of these observations, we speculated that Fn14 may modulate signal transduction by Rac1 or Cdc42, or both.

To test this hypothesis, we compared the subcellular localization of Fn14 and Rho family GTPases. COS-7 cells were cotransfected with plasmids encoding GFP-tagged Fn 14 and myc-tagged Rho family GTPases. As in PC12 cells, Fn14 is enriched within leading edge ruffles and dorsal ruffles (Fig. 7). In these locations, Fn14 is colocalized with F-actin. The distribution of RhoA partially overlaps with that of Rac1, Cdc42, and Fn14 but can be distinguished by its absence from dorsal ruffles. The colocalization of Fn14 with Rac1 and Cdc42 is consistent with one or both G-proteins participating in the neuritogenic effects of Fn 14 .

If Rac1 or Cdc42 participate in Fn14 action, then they may be present in a physical complex with Fn14. Myc epitope-tagged Rho family proteins were coexpressed with HA epitope-tagged Fn14 in HEK293T cells. Rac and Cdc42 immunoprecipitates were examined for associated Fn14. Only Rac1 immunoprecipitates contain Fn14 despite equal expression of the closely related G-protein, Cdc42 (Fig. 8 A). Some G-protein interactions are dependent on the activation state of the G-protein; however, Fn 14 coimmunoprecipitates equally well with wild-type, constitutively active, and dominant-negative Racl. The equal binding to all forms of Rac1 raises the possibility that Fn14 does not directly alter the Racl activation state. Indeed, PAK pull-down assays of activated Racl demonstrate no alteration of total activated Rac1 in Fn14-expressing cells (Fig. 8B). Thus, Fn14 colocalizes with Rac1, physically associates with Rac1, and produces a phenotype resembling that of activated Rac1 when overexpressed in PC12 cells.

The immunoprecipitation results do not distinguish between a direct and an indirect Rac1/Fn14 association. In experiments using recombinant Rac1 purified from bacterial cells, there was no detectable interaction with purified fragments of Fn14 (data not shown). This suggests that additional cellular proteins participate in the Rac1/Fn14 complex detected in HEK293T cells.

\section{Fn14-induced neuritogenesis requires Racl}

If Fn14 effects are mediated via a protein complex that includes Racl, then inactivation of Racl should block the neuritogenesis induced by Fn 14 overexpression. To assess the role of Racl activity in Fn14 neuritogenesis, PC12 cells were transfected with an 
A $\quad$ Fn14

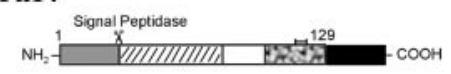

Fn14- $\triangle$ END

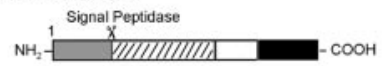

Fn14- $\triangle$ ECT
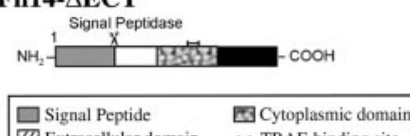
$\square$ Extracellular domain $\rightarrow$ TRAF-binding site $\square$ Transmembrane domain $\mathbf{G F P}$

\section{B}

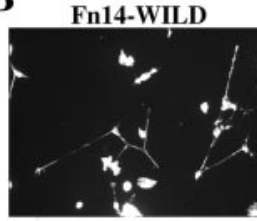

Fn14- $\triangle$ END

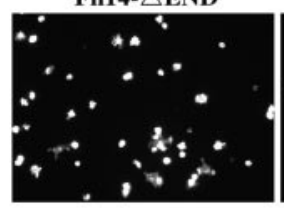

C

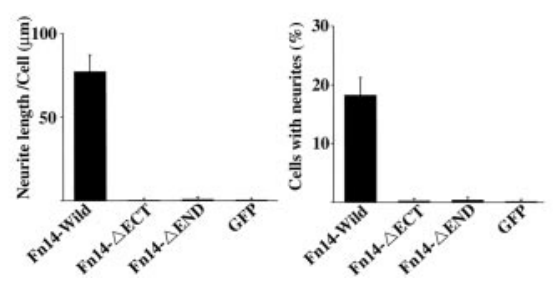

D

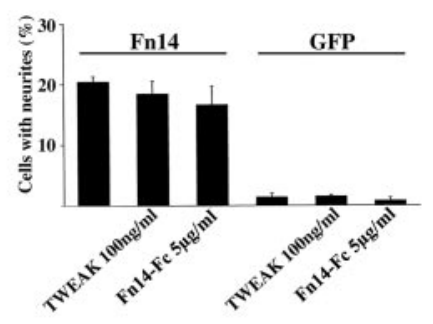

$\mathbf{E}$

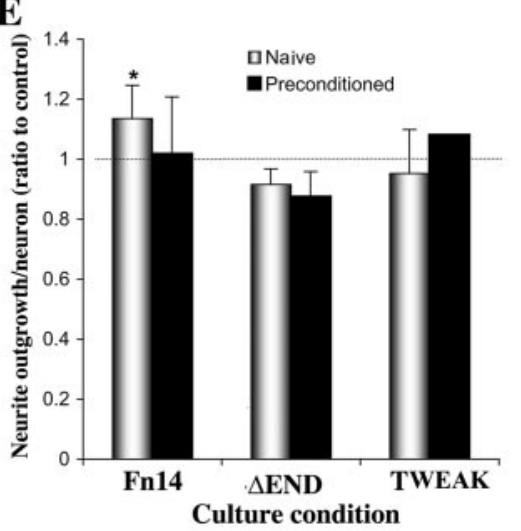

F

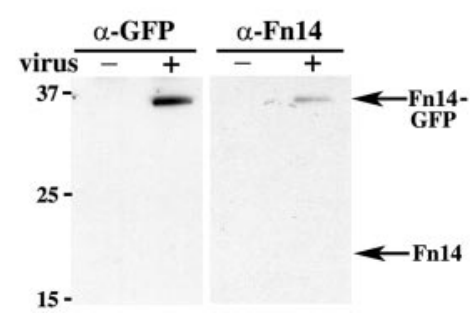

Figure 4. Fn14 overexpression in PC12 cells promotes neurite outgrowth. $A, A$ schematic of Fn14 protein features and the mutant forms of the protein that were expressed here. B, PC12 cells were cultured for $24 \mathrm{hr}$ after infection with HSV-Fn14wildGFP, HSV-Fn14 $\Delta$ ECT-GFP, HSV-Fn14 $D$ END-GFP, and HSV-GFP. Cellular F-actin was visualized with rhodamine-phalloidin staining. C, Neurite length per cell and the percentage of cells with neurites in PC12 cells after infection. Data are means \pm SEM from four independent experiments. A significant ( $p \leq 0.01$; Student's two-tailed $t$ test) increase in neurite outgrowth is observed in PC12 cells with HSV-Fn14wild-GFP compared with control cells with HSV-GFP. D, The percentage of PC12 cells with neurites after infection with each HSV virus and the addition of no protein, TWEAK (100 ng/ml), or Fn14 -Fc (5 $\mu \mathrm{g} / \mathrm{ml})$ to the culture media. Data are means \pm SEM from four independent experiments. No significant change of the percentage of neuritebearing cells is observed by the addition of recombinant TWEAK or Fn14-Fc. E, Regulation of DRG outgrowth by Fn14. Dissociated adult mouse DRG neurons were cultured from naive animals or animals undergoing sciatic nerve lesion 1 week before harvest of the axotomized DRG (preconditioned). The neurons were infected with HSV-Fn14wild-GFP, HSV-Fn14 $D$ END-GFP, or HSV-GFP. Some HSV-GFP cultures were treated with TWEAK ( $100 \mathrm{ng} / \mathrm{ml})$. Neurite outgrowth in GFP-expressing neurons was quantitated after 12-18 hr and is expressed as a percentage of the HSV-GFP control value for each culture. A significant ( $p \leq 0.05$; Student's two-tailed $t$ test) increase in neurite outgrowth is observed for naive DRG outgrowth from cells with HSV-Fn14wild-GFP compared with with HSV-Fn14 $\triangle$ END-GFP.F, Expression of recombinant Fn14-GFP protein in DRG neurons. Immunoblot for either Fn14 or GFP demonstrates Fn14 overexpression levels in HSV-Fn14 -GFP-infected DRG cultures.

\section{Discussion}

In the present study, we identified a number of genes with altered neuronal expression after peripheral nerve injury. Among them, we demonstrate that Fn14 has a regeneration-specific role in neuritogenesis that requires Racl but not the Fn14 ligand TWEAK. Fn14 colocalizes in F-actin-rich structures with Racl and physically associates with Racl. Furthermore, Fn14 overexpression in PC12 cells produces a phenotype resembling that of activated Rac1, and this effect is blocked by dominant-negative Racl. These studies identify a novel pathway that may contribute to the process of axonal regeneration in vivo.

\section{Microarray analysis for detection of} nerve regeneration-associated genes Thirty-eight RAGs were identified by our microarray studies of sciatic nerve regeneration, with 5 being recognized previously and 33 unreported previously. Significant upregulation of four previously unreported genes (myosin-X, SOX11, FLRT3, Fn14) was validated. Myosin-X is an unconventional myosin that is reported to shuttle along filopodia and increase their number (Berg and Cheney, 2002). Because filopodia motility is essential for growth cone guidance, enhanced expression of myosin-X suggests that myosin-X might contribute to axonal guidance during neuronal development and regeneration. SOX11 is a transcription factor involved in neuronal differentiation (Uwanogho et al., 1995; Hargrave et al., 1997; Rex et al., 1998; Hyodo-Miura et al., 2002); however, the role of SOX11 in mature differentiated neurons has not been explored, and this study is the first report of upregulated SOX11 expression during nerve regeneration. The FLRT3 gene encodes a protein that may function as a cell surface receptor, but no ligand or functional biology is known (Lacy et al., 1999). All three of these genes are also expressed in developing DRG, and a role in regeneration would support the dogma that regeneration recapitulates development. activated, wild-type, or dominant-negative Racl expression vector and replated to laminin-coated chamber slides before infection with HSV-Fn14-GFP or HSV-GFP. After $24 \mathrm{hr}$, neurite outgrowth is stimulated to a similar extent in cells coexpressing Fn14 plus wild-type Rac1 and in cells expressing activated G12VRac1 and GFP (Fig. 9). The effects of Fn14 and G12VRac1 are synergistic, leading to $>50 \%$ of coexpressing cells extending neurites. In contrast, dominant-negative T17NRac1 suppressed the neuritogenic effect of Fn14. Thus, Fn14 and activated Rac1 appear to act in the same pathway and Fn14 activity requires Racl function.

\section{Fn14 expression in regenerating DRG neurons}

The fourth RAG examined, Fn14, is induced in neurons during peripheral nerve regeneration but is not present during neural development. In this regard, it does not fit the developmental paradigm for axonal regeneration. There is growing precedence for such a separation of these processes. Our previous studies on SPRR1A identified another RAG that distinguished regenerative axon growth from developmental axonal extension (Bonilla et al., 2002). Similarly, JAK-STAT signaling appears to play a role selectively in regenerative growth from DRG (Liu and Snider, 2001). Although TWEAK can serve as a ligand for Fn14 in endo- 
thelial cells (Wiley et al., 2001; Harada et al., 2002; Donohue et al., 2003), we did not find evidence for compensatory or parallel regulation of Fn14 and TWEAK during nerve regeneration. Similarly, functional studies of axon outgrowth and Fn14 argue against a role for TWEAK. Thus, the function of Fn14 in this context appears to be ligand independent. Ligand-independent, TNF receptor-associated factor (TRAF)dependent Fn14 activation of nuclear factor $-\kappa \mathrm{B}(\mathrm{NF}-\kappa \mathrm{B})$ has been reported (Brown et al., 2003). Thus, the absence of a role for TWEAK is perhaps not surprising for these Fn14-sensitive neuronal cultures.

Fn14 overexpression promotes growthcone formation and neurite outgrowth Although PC12 cells normally possess low levels of Fn14, overexpression of the protein induces filopodia, lamelipodia, and neuritogenesis. In NGF-differentiated cultures, Fn14 overexpression promotes growth cone formation. A direct role for Fn14 in forming filopodia, neurites, and growth cones is supported by the localization of Fn14 protein to these structures and its colocalization with F-actin and GAP-43. These effects are clear in PC12 cells that otherwise exhibit few or no neurites and growth cones. For DRG neurons, axon growth is robust in culture, and minimal enhancement by Fn14 overexpression is observed in comparison only with cells expressing a potentially dominantnegative Fn14 truncation mutant (Fig. 4). The lack of Fn14-stimulated outgrowth in adult DRG neurons suggests that Fn14 function in DRG cultures may be redundant with other outgrowth-promoting mechanisms. Other relevant pathways are likely to be numerous and may include, but not be limited to, GAP-43 and SPRR1A induction (Skene, 1989; Bonilla et al., 2002).

\section{Interaction of Fn14 with Rac1}

Rho family GTPases are known to play central roles in regulating growth cone motility and neurite extension (Mackay et al., 1995; Hall, 1998; Dickson, 2001; Meyer and Feldman, 2002). Several lines of evidence demonstrate that Fn14 promotes neuritogenesis and growth cone formation by interactions with Racl. The two proteins colocalize and can be coimmunopre-

cipitated from transfected cells. In addition, activated Rac1 produces a PC12 phenotype similar to that of Fn14 overexpression, and dominant-negative Rac1 blocks Fn14-induced neuritogenesis. It is notable that expression of constitutively active Rac1 in DRG neurons does not enhance axon growth (Jin and Strittmatter, 1997), a negative finding that parallels the reduced activity of Fn14 overexpression in these rapidly growing axons. For PC12
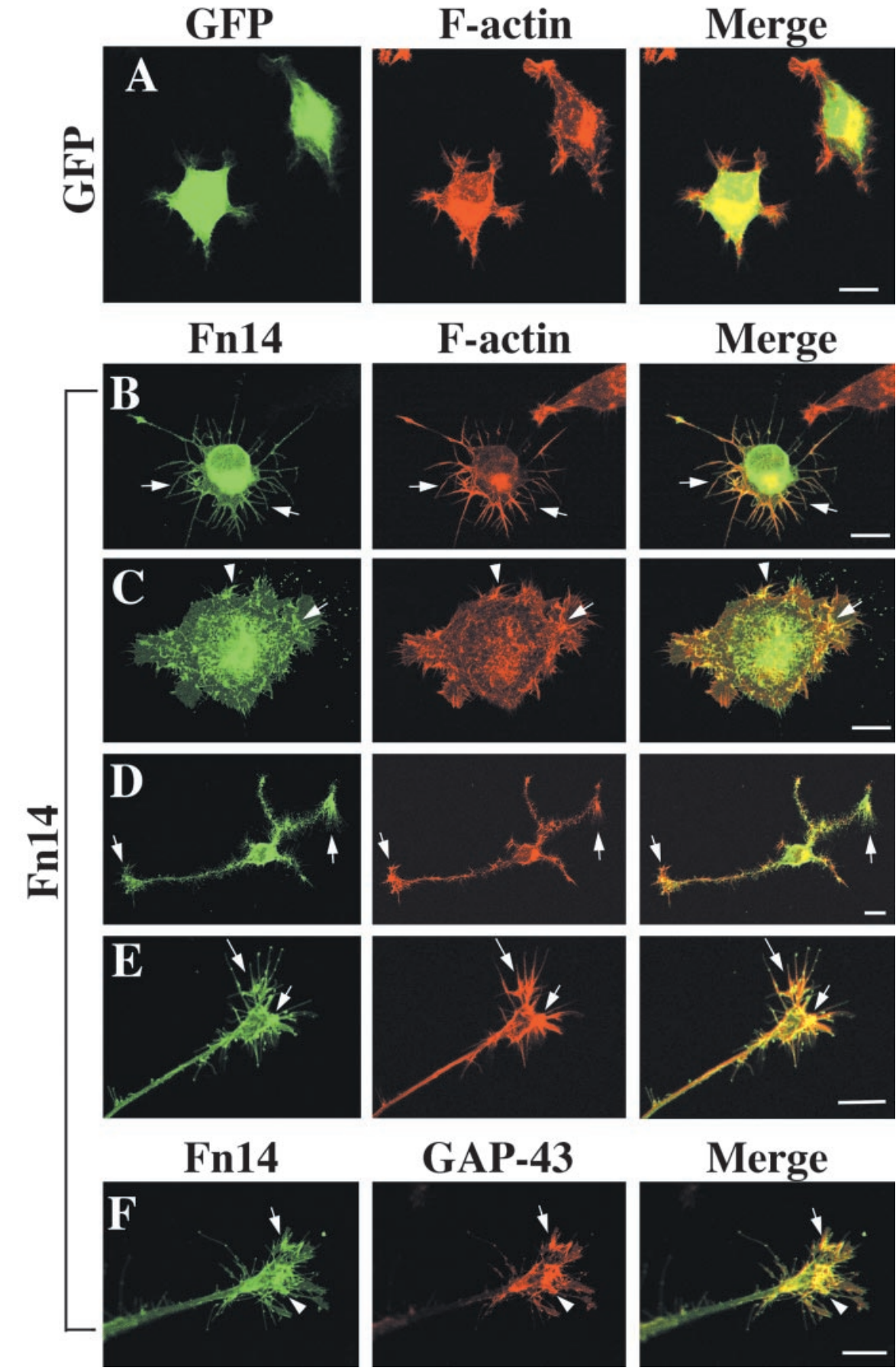

Figure 5. Fn14 overexpression in $\mathrm{PC} 12$ cells enhances filopodial and growth cone formation. $A-E, \mathrm{PC} 12$ cells were cultured for $24 \mathrm{hr}$ after infection with HSV-GFP or HSV-Fn14wild-GFP and examined for GFP (green) and F-actin (red, rhodamine-phalloidin). Although HSV-GFP has no effect on cell morphology $(A)$, overexpression of Fn14 induces a number of long filopodia extending from straight cell borders and from angular cell borders ( $B)$. Spreading and lamelipodial formation is also observed in Fn14-expressing PC12 cells ( $C$. Filopodia and lamelipodia are seen at the distal ends of formed growth cones (D, E). Fn14 and F-actin are well colocalized near the cell perimeter and in filopida and lamelipodia (arrows).F, After HSV-Fn14wild-GFP infection, GAP-43 (red) is expressed abundantly in filopodia and lamelipodia and colocalized with Fn14 (arrows). Scale bars, $10 \mu \mathrm{m}$.

cells, an Fn14 complex with Rac1 and other unidentified proteins appears capable of promoting axon outgrowth.

Fn14, like other TNF superfamily receptors, is associated via its cytoplasmic domain with adaptor proteins termed TRAFs (Wiley et al., 2001; Brown et al., 2003). Several specific TRAF isoforms are known to associate with the Fn14 cytoplasmic domain. In general, the TRAFs are known to be crucial for linking 
A
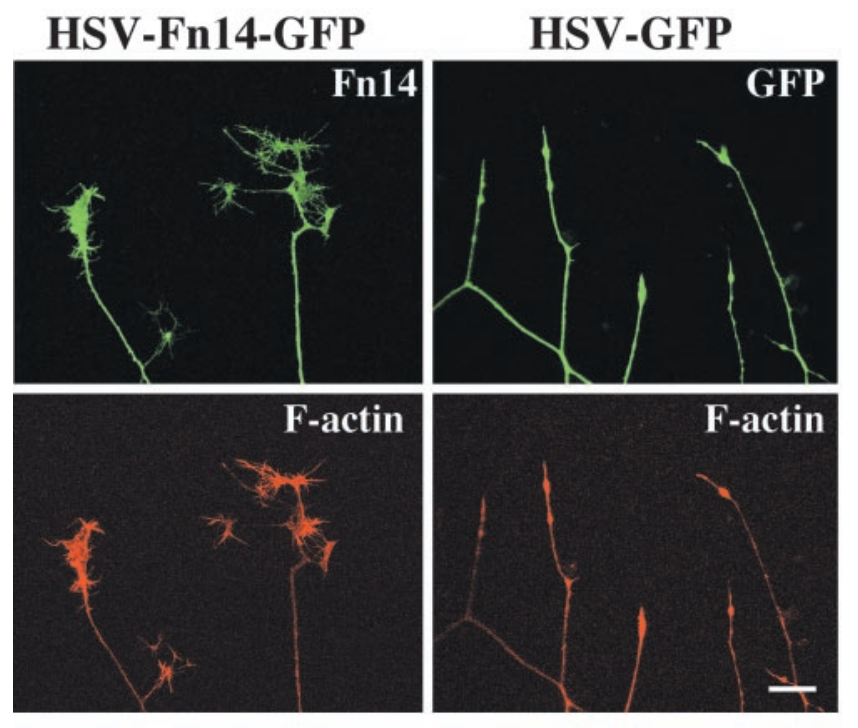

B

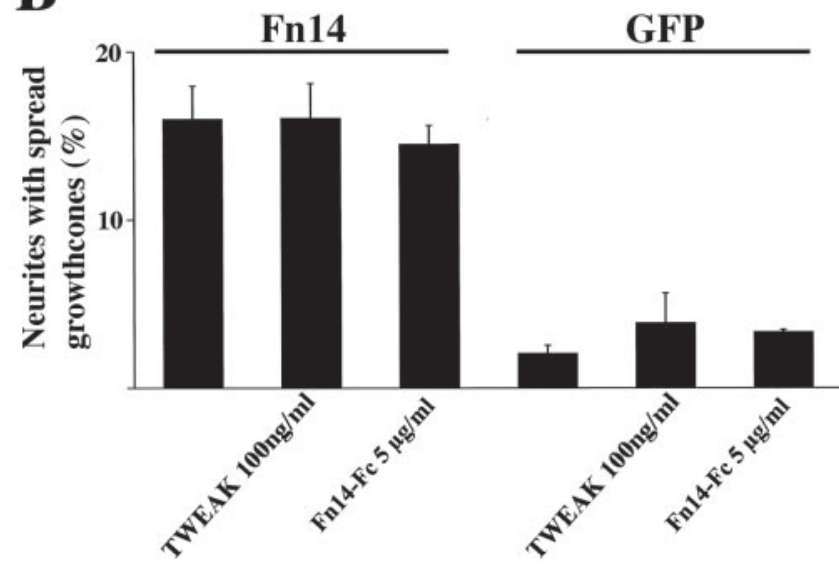

Figure 6. Fn14 promotes growth cone formation in differentiated $\mathrm{PC} 12$ cells. $\mathrm{PC} 12$ cells were differentiated for $9 \mathrm{~d}$ in the presence of NGF and then examined $24 \mathrm{hr}$ after infection with HSV-GFP or HSV-Fn14-GFP. A, Fn14-GFP and GFP fluorescence are shown in green, whereas rhodamine-phalloidin staining of $\mathrm{F}$-actin is red. Fn14 overexpression promotes growth cone formation compared with GFP control. Scale bar, $10 \mu \mathrm{m}$. B, The percentage of neurites with growth cones after infection with HSV-GFP or HSV-Fn14-GFP. In some cases, TWEAK (100 $\mathrm{ng} / \mathrm{ml})$ or $\mathrm{Fn} 14-\mathrm{Fc}(5 \mu \mathrm{g} / \mathrm{ml})$ was added to the culture media at the time of viral infection as indicated. Overexpression of Fn14 significantly ( $p \leq 0.01$; Student's two-tailed $t$ test) induces growth cone formation compared with GFP control. Neither TWEAK nor Fn14-Fc significantly alters growth cone formation. Data are means \pm SEM from three independent experiments.

the TNF family receptors to NF- $\kappa \mathrm{B}$ activation. There is also some evidence, however, that TNF receptor/TRAF complexes can couple to Rho family G-proteins in non-neuronal cells (Min and Pober, 1997; Puls et al., 1999), providing one potential explanation for the neurite outgrowth effects observed here.

The effect of Fn14 expression on Racl activation is not clear from this work. The Fn14 phenotype in PC12 cells resembles that of activated Racl. Therefore, the simplest model would be that the complex formation between Fn14 and Rac1 leads to G-protein activation. Fn14 overexpression, however, does not increase the proportion of activated Racl in the cell, and Fn14 has no binding preference for active versus inactive Racl. Although most G-protein-regulating proteins exhibit a strong preference

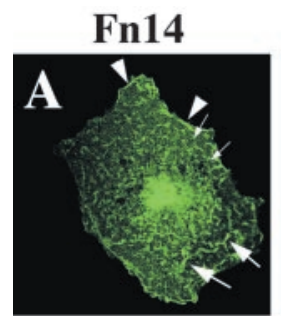

Fn14

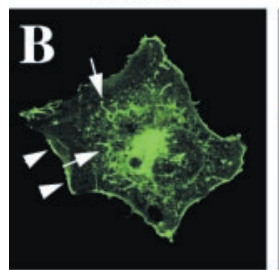

Fn14

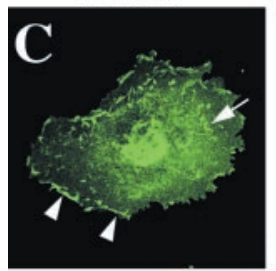

Fn14

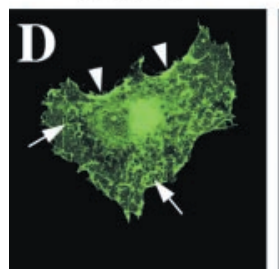

F-actin

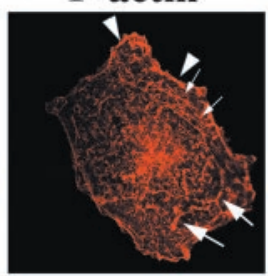

Cdc42

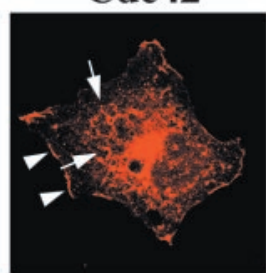

Rac1

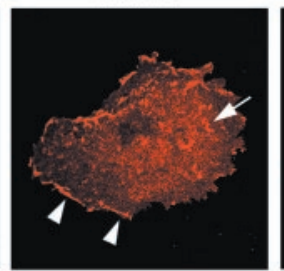

RhoA

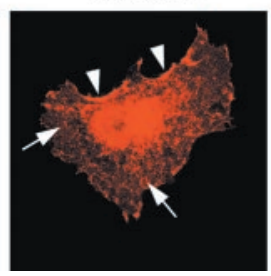

Merge

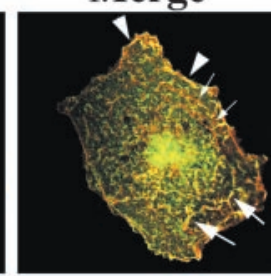

Merge

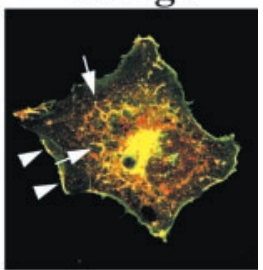

Merge

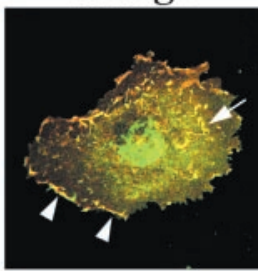

Merge

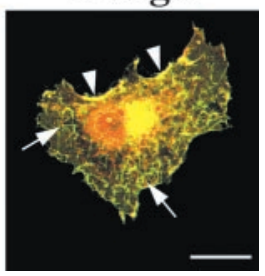

Figure 7. Fn14 colocalizes with Cdc42 and Rac1. Cos-7 cells were cotransfected with GFPtagged Fn14 and myc -tagged wild-type Rho family GTPases. F-actin was visualized with rhodamine-phalloidin, and Rho family GTPases were visualized with 9E10 anti-myc antibody and Cy3-conjugated anti-mouse lgG antibody. A, Fn14 accumulates and colocalizes with F-actin at dorsal ruffles (arrowheads) and leading edge ruffles (arrows) but not at stress fibers (small arrows). $B, C, C d c 42$ and Rac1 distribution overlap extensively with that of $F n 14$ at dorsal ruffles (arrows) and leading edge ruffles (arrowheads). D, RhoA colocalizes with Fn14 at leading edge ruffles (arrowheads) but not at dorsal ruffles (arrows). Scale bar, $20 \mu \mathrm{m}$.

for either the active GTP-bound or inactive GDP-bound state, there is precedent for other proteins with nucleotide-ambivalent Rho family interactions. Drosophila PlexinB receptors bind RhoGTP and Rho-GDP equally well, but reducing Rho gene dosage suppresses PlexinB gain-of-function phenotypes ( $\mathrm{Hu}$ et al., 2001). The clearest example of a protein that interacts strongly with both Rac-GTP and Rac-GDP is the Rho-GDI protein (Nomanbhoy and Cerione, 1996; Hoffman et al., 2000). Rho-GDI binds both states of Rho family proteins and inhibits both GTP hydrolysis and GDP release. Its in vivo activity is attributable primarily to a third activity, that of binding the geranylgeranyl moeity of the G-protein and sequestering the protein from the plasma membrane to the cytosol. Recently, several receptor systems have been shown to regulate Rho family activity indirectly by altering interactions between the G-protein and Rho-GDI (Takahashi et al., 1997; Del Pozo et al., 2002; Yamashita and Tohyama, 2003). The effect of Fn14 on Rac signaling cascades is not fully defined. It may be that the Fn 14 effect is to relocalize and concentrate Racl to sites more prone to lead to growth cone formation without changing its activation state. The effect would 
be opposite to Rho-GDI, moving the protein from the cytosol to the membrane. Alternatively, Fn14 and associated proteins may activate a small proportion of Racl locally that is not detected under our experimental conditions. Nonetheless, Rac1 is essential for Fn14-induced neuritogenesis.

\section{Conclusion}

A microarray method has been used successfully to identify numerous regenerationassociated genes in DRG after sciatic nerve transection. Although some of these are well characterized and exhibit a coordinated expression in development and regeneration, Fn14 is one of a smaller group that is expressed more selectively during regeneration. Here we provide evidence that Fn14 overexpression promotes neurite extension and growth cone formation in PC12 cells. Fn14 associates with the Rho family GTPase Rac1, and Rac1 is necessary for the Fn14induced neuronal cell effects. These data further expand the range of mechanisms capable of contributing to regenerative axon growth after injury.

\section{References}

Araki T, Nagarajan R, Milbrandt J (2001) Identification of genes induced in peripheral nerve after injury. Expression profiling and novel gene discovery. J Biol Chem 276:34131-34141.

Benn SC, Perrelet D, Kato AC, Scholz J, Decosterd I, Mannion RJ, Bakowska JC, Woolf CJ (2002) Hsp27 upregulation and phosphorylation is required for injured sensory and motor neuron survival. Neuron 36:45-56.

Berg JS, Cheney RE (2002) Myosin-X is an unconventional myosin that undergoes intrafilopodial motility. Nat Cell Biol 4:246-250.

Berg JS, Derfler BH, Pennisi CM, Corey DP, Cheney RE (2000) Myosin-X, a novel myosin with pleckstrin homology domains, associates with regions of dynamic actin. J Cell Sci 113:3439-3451.

Bonilla IE, Tanabe K, Strittmatter SM (2002) Small proline-rich repeat protein $1 \mathrm{~A}$ is expressed by axotomized neurons and promotes axonal outgrowth. J Neurosci 22:1303-1315.

Bregman BS, Coumans JV, Dai HN, Kuhn PL, Lynskey J, McAtee M, Sandhu F (2002) Transplants and neurotrophic factors increase regeneration and recovery of function after spinal cord injury. Prog Brain Res 137:257-273.

Brown SA, Richards CM, Hanscom HN, Feng SL, Winkles JA (2003) The Fn14 cytoplasmic tail binds tumour-necrosis-factor-receptor-associated factors 1, 2, 3 and 5 and mediates nuclear factor-kappaB activation. Biochem J 371:395-403.

Chen XQ, Tan I, Leung T, Lim L (1999) The myotonic dystrophy kinaserelated Cdc42-binding kinase is involved in the regulation of neurite outgrowth in PC12 cells. J Biol Chem 274:19901-19905.

Chong MS, Woolf CJ, Haque NS, Anderson PN (1999) Axonal regeneration from injured dorsal roots into the spinal cord of adult rats. J Comp Neurol 410:42-54.

Costigan M, Mannion RJ, Kendall G, Lewis SE, Campagna JA, Coggeshall RE, Meridith-Middleton J, Tate S, Woolf CJ (1998) Heat shock protein 27: developmental regulation and expression after peripheral nerve injury. J Neurosci 18:5891-5900.

Costigan M, Befort K, Karchewski L, Griffin RS, Da'Urso D, Allchorne A, Sitarski J, Mannion JW, Pratt RE, Woolf CJ (2002) Replicate highdensity rat genome oligonucleotide microarrays reveal hundreds of regulated genes in the dorsal root ganglion after peripheral nerve injury. BMC Neurosci 3:16.

Coumans JV, Lin TT, Dai HN, MacArthur L, McAtee M, Nash C, Bregman BS (2001) Axonal regeneration and functional recovery after complete spinal cord transection in rats by delayed treatment with transplants and neurotrophins. J Neurosci 21:9334-9344.

Daniels RH, Hall PS, Bokoch GM (1998) Membrane targeting of p21-
Fn14-HA

B

Fn14-HA Mock

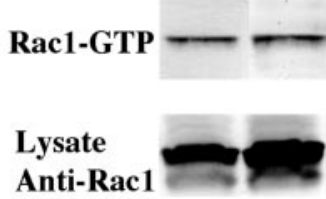

Lysate

Anti-HA

Figure 8. Fn14 interacts physically with Rac1. A, Coimmunoprecipitation of Fn14-HA with myc-tagged wild-type, constituA antibody. The amount of GTP-bound (active) Rac1 is not altered by overexpression of Fn14.

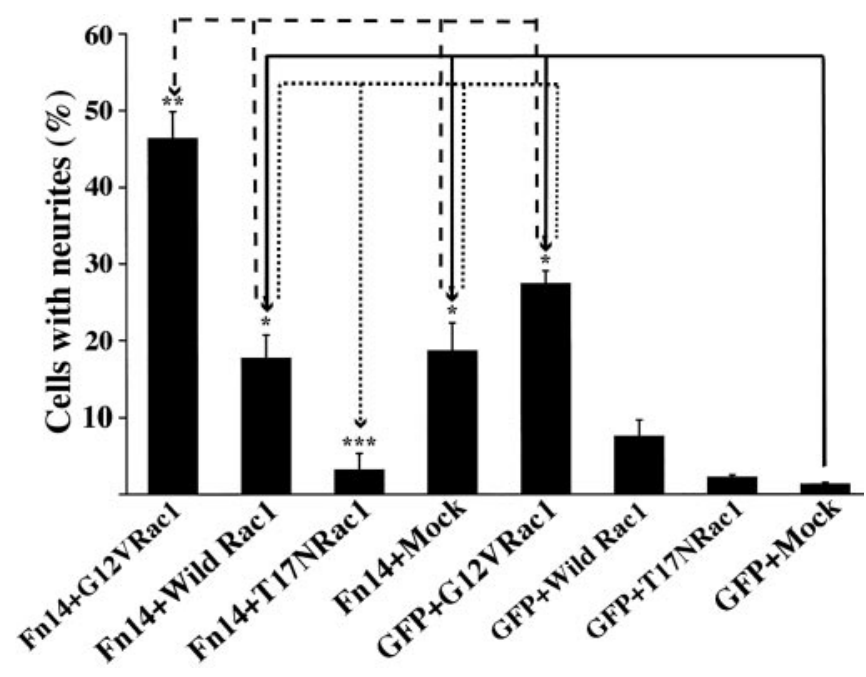

Figure 9. Fn14-induced PC12 neurite outgrowth requires Rac1 function. Constitutively active (G12V), dominant-negative (T17N), or wild-type Rac1 was coexpressed with Fn14-GFP (Fn14) or GFP in PC12 cells, and neurite outgrowth was assessed. Expression of Rac1G12V + GFP, Rac1wild + Fn14-GFP, or Fn14-GFP alone (+ Mock) increased neurite outgrowth significantly, compared with GFP-expressing cells ( ${ }^{*} p \leq 0.01$; Student's two-tailed $t$ test). Coexpression of Rac1G12V with Fn14-GFP increased outgrowth to levels greater than that observed with Rac1G12V + GFP, Rac1wild + Fn14-GFP, or Fn14-GFP expression ( ${ }^{* *} p \leq 0.05$; Student's two-tailed $t$ test). Cells expressing Rac1T17N with Fn14-GFP exhibited outgrowth indistinguishable from control GFP-expressing cells and significantly less outgrowth than those cells expressing Rac1G12V+GFP, Rac1wild + Fn14-GFP, or Fn14-GFP alone (*** $p \leq 0.05$; Student's two-tailed $t$ test). Data are the means \pm SEM from three independent experiments.

activated kinase 1 (PAK1) induces neurite outgrowth from PC12 cells. EMBO J 17:754-764.

Del Pozo MA, Kiosses WB, Alderson NB, Meller N, Hahn KM, Schwartz MA (2002) Integrins regulate GTP-Rac localized effector interactions through dissociation of Rho-GDI. Nat Cell Biol 4:232-239.

Desplat-Jego S, Varriale S, Creidy R, Terra R, Bernard D, Khrestchatisky M, Izui S, Chicheportiche Y, Boucraut J (2002) TWEAK is expressed by glial cells, induces astrocyte proliferation and increases EAE severity. J Neuroimmunol 133:116-123.

Dickson BJ (2001) Rho GTPases in growth cone guidance. Curr Opin Neurobiol 11:103-110.

Donohue PJ, Richards CM, Brown SA, Hanscom HN, Buschman J, Thangada S, Hla T, Williams MS, Winkles JA (2003) TWEAK is an endothelial cell 
growth and chemotactic factor that also potentiates FGF-2 and VEGF-A mitogenic activity. Arterioscler Thromb Vasc Biol 23:594-600.

Fawcett JW, Asher RA (1999) The glial scar and central nervous system repair. Brain Res Bull 49:377-391.

Fournier AE, Strittmatter SM (2001) Repulsive factors and axon regeneration in the CNS. Curr Opin Neurobiol 11:89-94.

Funakoshi H, Frisen J, Barbany G, Timmusk T, Zachrisson O, Verge VM, Persson H (1993) Differential expression of mRNAs for neurotrophins and their receptors after axotomy of the sciatic nerve. J Cell Biol 123:455-465.

Goldberg JL, Klassen MP, Hua Y, Barres BA (2002) Amacrine-signaled loss of intrinsic axon growth ability by retinal ganglion cells. Science 296:1860-1864

GrandPre T, Nakamura F, Vartanian T, Strittmatter SM (2000) Identification of the Nogo inhibitor of axon regeneration as a Reticulon protein. Nature 403:439-444.

GrandPre T, Li S, Strittmatter SM (2002) Nogo-66 receptor antagonist peptide promotes axonal regeneration. Nature 417:547-551.

Hall A (1998) Rho GTPases and the actin cytoskeleton. Science 279:509-514.

Harada N, Nakayama M, Nakano H, Fukuchi Y, Yagita H, Okumura K (2002) Pro-inflammatory effect of TWEAK/Fn14 interaction on human umbilical vein endothelial cells. Biochem Biophys Res Commun 299:488-493.

Hargrave M, Wright E, Kun J, Emery J, Cooper L, Koopman P (1997) Expression of the Sox11 gene in mouse embryos suggests roles in neuronal maturation and epithelio-mesenchymal induction. Dev Dyn 210:79-86.

Hoffman GR, Nassar N, Cerione RA (2000) Structure of the Rho family GTP-binding protein Cdc42 in complex with the multifunctional regulator RhoGDI. Cell 100:345-356.

Hu H, Marton TF, Goodman CS (2001) Plexin B mediates axon guidance in Drosophila by simultaneously inhibiting active Rac and enhancing RhoA signaling. Neuron 32:39-51.

Hyodo-Miura J, Urushiyama S, Nagai S, Nishita M, Ueno N, Shibuya H (2002) Involvement of NLK and Sox11 in neural induction in Xenopus development. Genes Cells 7:487-496.

Jalink K, van Corven EJ, Hengeveld T, Morii N, Narumiya S, Moolenaar WH (1994) Inhibition of lysophosphatidate- and thrombin-induced neurite retraction and neuronal cell rounding by ADP ribosylation of the small GTP-binding protein Rho. J Cell Biol 126:801-810.

Jay P, Goze C, Marsollier C, Taviaux S, Hardelin JP, Koopman P, Berta P (1995) The human SOX11 gene: cloning, chromosomal assignment and tissue expression. Genomics 29:541-545.

Jin Z, Strittmatter SM (1997) Rac1 mediates collapsin-1-induced growth cone collapse. J Neurosci 17:6256-6263.

Kiryu S, Yao GL, Morita N, Kato H, Kiyama H (1995) Nerve injury enhances rat neuronal glutamate transporter expression: identification by differential display PCR. J Neurosci 15:7872-7878.

Kozma R, Ahmed S, Best A, Lim L (1995) The Ras-related protein Cdc42Hs and bradykinin promote formation of peripheral actin microspikes and filopodia in Swiss 3T3 fibroblasts. Mol Cell Biol 15:1942-1952.

Kozma R, Sarner S, Ahmed S, Lim L (1997) Rho family GTPases and neuronal growth cone remodeling: relationship between increased complexity induced by $\mathrm{Cdc} 42 \mathrm{Hs}$, Racl, and acetylcholine and collapse induced by RhoA and lysophosphatidic acid. Mol Cell Biol 17:1201-1211.

Lacy SE, Bonnemann CG, Buzney EA, Kunkel LM (1999) Identification of FLRT1, FLRT2, and FLRT3: a novel family of transmembrane leucinerich repeat proteins. Genomics 62:417-426.

Landry M, Holmberg K, Zhang X, Hokfelt T (2000) Effect of axotomy on expression of NPY, galanin, and NPY Y1 and Y2 receptors in dorsal root ganglia and the superior cervical ganglion studied with double-labeling in situ hybridization and immunohistochemistry. Exp Neurol 162:361-384.

Lewis SE, Mannion RJ, White FA, Coggeshall RE, Beggs S, Costigan M, Martin JL, Dillmann WH, Woolf CJ (1999) A role for HSP27 in sensory neuron survival. J Neurosci 19:8945-8953.

Liu RY, Snider WD (2001) Different signaling pathways mediate regenerative versus developmental sensory axon growth. J Neurosci 21:RC164(1-5).

Lynch CN, Wang YC, Lund JK, Chen YW, Leal JA, Wiley SR (1999) TWEAK induces angiogenesis and proliferation of endothelial cells. J Biol Chem 274:8455-8459.

Mackay DJ, Nobes CD, Hall A (1995) The Rho's progress: a potential role during neuritogenesis for the Rho family of GTPases. Trends Neurosci 18:496-501.

Mattsson P, Morgan BP, Svensson M (1998) Complement activation and CD59 expression in the motor facial nucleus following intracranial transection of the facial nerve in the adult rat. J Neuroimmunol 91:180-189.

McKerracher L, David S, Jackson DL, Kottis V, Dunn RJ, Braun PE (1994) Identification of myelin-associated glycoprotein as a major myelinderived inhibitor of neurite growth. Neuron 13:805-811.

Meighan-Mantha RL, Hsu DK, Guo Y, Brown SA, Feng SL, Peifley KA, Alberts GF, Copeland NG, Gilbert DJ, Jenkins NA, Richards CM, Winkles JA (1999) The mitogen-inducible Fn14 gene encodes a type I transmembrane protein that modulates fibroblast adhesion and migration. J Biol Chem 274:33166-33176.

Meyer G, Feldman EL (2002) Signaling mechanisms that regulate actinbased motility processes in the nervous system. J Neurochem 83:490-503.

Min W, Pober JS (1997) TNF initiates E-selectin transcription in human endothelial cells through parallel TRAF-NF-kappa B and TRAF-RAC/ CDC42-JNK-c-Jun/ATF2 pathways. J Immunol 159:3508-3518.

Moskowitz PF, Oblinger MM (1995) Sensory neurons selectively upregulate synthesis and transport of the $\beta$ III-tubulin protein during axonal regeneration. J Neurosci 15:1545-1555.

Muma NA, Hoffman PN, Slunt HH, Applegate MD, Lieberburg I, Price DL (1990) Alterations in levels of mRNAs coding for neurofilament protein subunits during regeneration. Exp Neurol 107:230-235.

Nakamura F, Tanaka M, Takahashi T, Kalb RG, Strittmatter SM (1998) Neuropilin-1 extracellular domains mediate semaphorin D/III-induced growth cone collapse. Neuron 21:1093-1100.

Neumann S, WoolfCJ (1999) Regeneration of dorsal column fibers into and beyond the lesion site following adult spinal cord injury. Neuron 23:83-91.

Niederost BP, Zimmermann DR, Schwab ME, Bandtlow CE (1999) Bovine CNS myelin contains neurite growth-inhibitory activity associated with chondroitin sulfate proteoglycans. J Neurosci 19:8979-8989.

Nobes CD, Hall A (1995) Rho, rac, and cdc42 GTPases regulate the assembly of multimolecular focal complexes associated with actin stress fibers, lamellipodia, and filopodia. Cell 81:53-62.

Nomanbhoy TK, Cerione R (1996) Characterization of the interaction between RhoGDI and $\mathrm{Cdc} 42 \mathrm{Hs}$ using fluorescence spectroscopy. J Biol Chem 271:10004-10009.

Puls A, Eliopoulos AG, Nobes CD, Bridges T, Young LS, Hall A (1999) Activation of the small GTPase Cdc42 by the inflammatory cytokines TNF(alpha) and IL-1, and by the Epstein-Barr virus transforming protein LMP1. J Cell Sci 112:2983-2992.

Qiu J, Cai D, Filbin MT (2002a) A role for cAMP in regeneration during development and after injury. Prog Brain Res 137:381-387.

Qiu J, Cai D, Dai H, McAtee M, Hoffman PN, Bregman BS, Filbin MT (2002b) Spinal axon regeneration induced by elevation of cyclic AMP. Neuron 34:895-903.

Rex M, Church R, Tointon K, Ichihashi RM, Mokhtar S, Uwanogho D, Sharpe PT, Scotting PJ (1998) Granule cell development in the cerebellum is punctuated by changes in Sox gene expression. Brain Res Mol Brain Res 55:28-34.

Richardson PM, McGuinness UM, Aguayo AJ (1980) Axons from CNS neurons regenerate into PNS grafts. Nature 284:264-265.

Ridley AJ, Hall A (1992) The small GTP-binding protein rho regulates the assembly of focal adhesions and actin stress fibers in response to growth factors. Cell 70:389-399.

Skene JH (1989) Axonal growth-associated proteins. Annu Rev Neurosci 12:127-156.

Skene JH, Willard M (1981) Axonally transported proteins associated with axon growth in rabbit central and peripheral nervous systems. J Cell Biol 89:96-103.

Takahashi K, Sasaki T, Mammoto A, Takaishi K, Kameyama T, Tsukita S, Takai Y (1997) Direct interaction of the Rho GDP dissociation inhibitor with ezrin/radixin/moesin initiates the activation of the Rho small G protein. J Biol Chem 272:23371-23375.

Takahashi T, Nakamura F, Jin Z, Kalb RG, Strittmatter SM (1998) Semaphorins $\mathrm{A}$ and $\mathrm{E}$ act as antagonists of neuropilin-1 and agonists of neuropilin-2 receptors. Nat Neurosci 1:487-493.

Takahashi T, Fournier A, Nakamura F, Wang LH, Murakami Y, Kalb RG, Fujisawa H, Strittmatter SM (1999) Plexin-neuropilin-1 complexes form functional semaphorin-3A receptors. Cell 99:59-69. 
Tanabe K, Nakagomi S, Kiryu-Seo S, Namikawa K, Imai Y, Ochi T, Tohyama M, Kiyama H (1999) Expressed-sequence-tag approach to identify differentially expressed genes following peripheral nerve axotomy. Brain Res Mol Brain Res 64:34-40.

Tanabe K, Tachibana T, Yamashita T, Che YH, Yoneda Y, Ochi T, Tohyama M, Yoshikawa H, Kiyama H (2000) The small GTP-binding protein TC10 promotes nerve elongation in neuronal cells, and its expression is induced during nerve regeneration in rats. J Neurosci 20:4138-4144.

Tanaka E, Sabry J (1995) Making the connection: cytoskeletal rearrangements during growth cone guidance. Cell 83:171-176.

Tigyi G, Fischer DJ, Sebok A, Yang C, Dyer DL, Miledi R (1996) Lysophosphatidic acid-induced neurite retraction in PC12 cells: control by phosphoinositide- $\mathrm{Ca}^{2+}$ signaling and Rho. J Neurochem 66:537-548.

Tsujino H, Kondo E, Fukuoka T, Dai Y, Tokunaga A, Miki K, Yonenobu K, Ochi T, Noguchi K (2000) Activating transcription factor 3 (ATF3) induction by axotomy in sensory and motoneurons: a novel neuronal marker of nerve injury. Mol Cell Neurosci 15:170-182.

Uwanogho D, Rex M, Cartwright EJ, Pearl G, Healy C, Scotting PJ, Sharpe PT (1995) Embryonic expression of the chicken Sox2, Sox3 and Sox 11 genes suggests an interactive role in neuronal development. Mech Dev 49:23-36.

Villar MJ, Cortes R, Theodorsson E, Wiesenfeld-Hallin Z, Schalling M, Fahrenkrug J, Emson PC, Hokfelt T (1989) Neuropeptide expression in rat dorsal root ganglion cells and spinal cord after peripheral nerve injury with special reference to galanin. Neuroscience 33:587-604.

Wakisaka S, Kajander KC, Bennett GJ (1991) Increased neuropeptide Y
(NPY)-like immunoreactivity in rat sensory neurons following peripheral axotomy. Neurosci Lett 124:200-203.

Wang KC, Koprivica V, Kim JA, Sivasankaran R, Guo Y, Neve RL, He Z (2002) Oligodendrocyte-myelin glycoprotein is a Nogo receptor ligand that inhibits neurite outgrowth. Nature 417:941-944.

Wiley SR, Cassiano L, Lofton T, Davis-Smith T, Winkles JA, Lindner V, Liu H, Daniel TO, Smith CA, Fanslow WC (2001) A novel TNF receptor family member binds TWEAK and is implicated in angiogenesis. Immunity 15:837-846.

Yamaguchi Y, Katoh H, Yasui H, Mori K, Negishi M (2001) RhoA inhibits the nerve growth factor-induced Racl activation through Rho-associated kinase-dependent pathway. J Biol Chem 276:18977-18983.

Yamashita T, Tohyama M (2003) The p75 receptor acts as a displacement factor that releases Rho from Rho-GDI. Nat Neurosci 6:461-467.

Yasui H, Katoh H, Yamaguchi Y, Aoki J, Fujita H, Mori K, Negishi M (2001) Differential responses to nerve growth factor and epidermal growth factor in neurite outgrowth of PC12 cells are determined by Racl activation systems. J Biol Chem 276:15298-15305.

Yonezawa S, Kimura A, Koshiba S, Masaki S, Ono T, Hanai A, Sonta S, Kageyama T, Takahashi T, Moriyama A (2000) Mouse myosin X: molecular architecture and tissue expression as revealed by northern blot and in situ hybridization analyses. Biochem Biophys Res Commun 271:526-533.

Zhang X, Bao L, Xu ZQ, Diez M, Frey P, Hokfelt T (1996) Peripheral axotomy induces increased expression of neurotensin in large neurons in rat lumbar dorsal root ganglia. Neurosci Res 25:359-369. 